\section{Global Sustainability}

cambridge.org/sus

\section{Review}

Cite this article: Loginova J, Batterbury SPJ (2019). Incremental, transitional and transformational adaptation to climate change in resource extraction regions. Global Sustainability 2, e17, 1-12. https://doi.org/ $10.1017 /$ sus.2019.14

Received: 31 December 2018

Revised: 11 August 2019

Accepted: 13 August 2019

\section{Key words:}

Adaptation and mitigation; Industrial activities; Policies; politics and governance

Author for correspondence:

Dr Simon P.J. Batterbury,

E-mail: simonpjb@unimelb.edu.au (c) The Author(s) 2019. This is an Open Access article, distributed under the terms of the Creative Commons Attribution licence (http:// creativecommons.org/licenses/by/4.0/), which permits unrestricted re-use, distribution, and reproduction in any medium, provided the original work is properly cited.

\title{
Incremental, transitional and transformational adaptation to climate change in resource extraction regions
}

\section{Julia Loginova ${ }^{1}$ (I) and Simon P.J. Batterbury ${ }^{2,3}$ (D)}

${ }^{1}$ School of Earth and Environmental Sciences, The University of Queensland, St Lucia, QLD 4072, Australia; ${ }^{2}$ School of Geography, The University of Melbourne, Parkville, VIC 3010, Australia and ${ }^{3}$ Lancaster Environment Centre, Lancaster University, Lancaster, LA1 4YQ, UK

\section{Non-technical summary}

Mining regions are affected by climate change. Supplies of energy and water are required, and operations become hazardous during adverse weather events. Adapting to climate change takes three forms: incrementally improving the resilience of mining operations; transitioning to more inclusive governance through institutional and policy innovations; and more profound transformations that shift the balance of power, including profit-sharing, localized control or cessation of mining entirely. Clarifying adaptation pathways helps to identify priorities and inform policies for a fairer and more sustainable future for mining and the regions where it takes place.

\section{Technical summary}

Mining regions are strategically important in the response to climate change given advances in global governance and shifting risks at extraction sites. There are sustainability and justice considerations that offer critical lessons for the design of climate change adaptation in these regions. This article systematically reviews and evaluates the social and interdisciplinary science literature on adaptation to climate change in mining regions in order to identify the goals and scale of proposed solutions, their shortcomings and possible learning opportunities. The review employs a framework of adaptation pathways that distinguishes between incremental, transitional and transformational adaptation. In this way, it contributes to the growing literature on resource extraction and climate change adaptation by providing further understanding of how adaptation in mining regions can and does occur. The review finds a lack of clarity in how adaptive responses and behaviours are framed. Conceptual lenses need to be multi-scalar, dynamic and polycentric, with more empirical and practical work to identify how to enable adaptation in mining regions, not only through deploying technology, but also through better governance practices and more egalitarian power structures.

\section{Social media summary}

There are various adaptation pathways for mining regions to meet threats and opportunities presented by climate change.

\section{Introduction}

Regions that host the extraction of hydrocarbons, metals and minerals (referred to henceforth as mining ${ }^{1}$ ) are strategically important in the response to anthropogenic climate change. Global advances in governance and growing awareness of climate change and its impacts are leading the mining industry, governments, civil society and other actors to make choices about technological, managerial and policy solutions that often clash with the continued demand for minerals and hydrocarbons (Odell et al., 2018). 'Adaptation', 'mitigation', 'resilience' and 'transitions' have gained prominence in policy, planning, research and social protest about mining, particularly following the warnings issued by the Intergovernmental Panel on Climate Change (IPCC) and the United Nations Framework Convention on Climate Change (UNFCCC), and sustained by the burgeoning literature on the topic.

From a normative perspective, better climate change responses in mining regions offer some hope of more sustainable development in a climate-resilient future (Addison, 2018;

\footnotetext{
${ }^{1}$ Defined here as a broad category that includes areas spatially and socioeconomically dependent on the extraction of minerals, metals and hydrocarbons. We refer to surface mining when soil, rock, liquids and gases are removed from the deposits and to underground mining when deposits and liquids are removed through shafts and tunnels still covered by soil and rocks. This includes fracking (Bridge, 2016)
} 
Table 1. Adaptation pathways (adapted from Pelling, 2011).

\begin{tabular}{|c|c|c|c|}
\hline Pathway & Incremental & Transitional & Transformational \\
\hline Goal & $\begin{array}{l}\text { Functional persistence in a changing } \\
\text { environment }\end{array}$ & $\begin{array}{l}\text { Realize full potential through the exercise of rights within } \\
\text { the established regime }\end{array}$ & $\begin{array}{l}\text { Reconfigure political economy of } \\
\text { development }\end{array}$ \\
\hline Scope & $\begin{array}{l}\text { Change in technology, management } \\
\text { practice and organization }\end{array}$ & $\begin{array}{l}\text { Change in governance practices to secure procedural } \\
\text { justice and incremental change in the governance system }\end{array}$ & $\begin{array}{l}\text { From individual behaviour to the } \\
\text { global political economy }\end{array}$ \\
\hline Time & Short to medium term & Medium to long term & Long term and intergenerational \\
\hline Scale & Local or regional & Regional or national & Multiple scales \\
\hline
\end{tabular}

Ali et al., 2017; Giurco \& Cooper, 2012; Hodgkinson \& Smith, 2018; Segura-Salazar \& Tavares, 2018). Viewed more critically, mining regions face the twin challenges of sustainability and justice. Issues include the 'resource curse' (Auty, 2002), pollution (O’Rourke \& Connolly, 2003), conflicts over access to natural resources (Bebbington \& Bury, 2013; Hilson, 2002) and the alienation of local communities (Kemp et al., 2011). Climate change has the potential to further aggravate existing social, environmental and economic vulnerabilities in mining regions (Phillips, 2016). Given these circumstances, one should be attentive to the extent that climate change responses can alter the complexities of regions where resource extraction is prioritized over other land uses. A key question is whether climate-resilient mining can exist at all, and in what form, in a nexus of communities, ecosystems and economies. A critical understanding of past and current initiatives is essential if maladaptation is to be avoided (Magnan et al., 2016).

The goal of this article is to provide a comprehensive review of climate change responses in mining regions for research to adequately inform policy and planning and so that vulnerabilities can be addressed in present and future mining regions. Asking what adaptation is for enables us to identify priorities for action and to locate some overlooked dimensions. This work is built on and extends academic literature that only begins to establish an understanding of the complex relationships between climate change and resource extraction (Odell et al., 2018; Phillips, 2016).

We systematically review and evaluate the scholarly literature that conceptualizes adaptation to climate change in mining regions and reports evidence of existing responses. We employ a framework of adaptation pathways developed by Pelling (2011) that distinguishes between incremental, transitional and transformational adaptation. In this framework, adaptation refers to changes in practices in response to a changing environment (Pelling, 2011). After introducing the conceptual framework, we present evidence of emerging public and private initiatives based on available documentation against the framework and explain the methodology for the review. We then provide a synthesis of current knowledge by identifying major research themes that focus on incremental, transitional and transformational adaptation in mining regions, and we conclude by identifying key knowledge gaps, future research needs and opportunities for social learning. We hope the audience will be planners, the development sector, the mining industry, host communities, activists and scholars interested in adaptation to climate change and the challenges of sustainability and justice raised by mining in a changing climate.

\section{A conceptual framework}

Adaptation has been a central concept in several disciplines in the environmental and social sciences (Hoffmann \& Sgro, 2011; Smit \& Wandel, 2006). It was first driven by evolutionary ideas and became a means for reflecting upon the link between society and the environment in a reciprocal way across scientific fields. Recently, the field of adaptation to climate change has gained prominence because of the acceleration of global environmental changes, an increased awareness about them and growing demands for adequate responses (Füssel, 2007).

Recent studies argue that contemporary challenges require approaches that integrate adaptation, mitigation and development (Naess et al., 2015; Thornton \& Comberti, 2017) and recognize interlinkages with sustainability and justice (Leach et al., 2018). Incremental adaptation to climate change is insufficient, and rather society-wide transformations that enable political economic change and more inclusive development are needed (Gillard et al., 2016; O'Brien, 2012; Park et al., 2012; Waddell et al., 2015). The framework of adaptation pathways proposed by Pelling (2011) is one comprehensive way to distinguish climate change responses aimed at proximate causes of vulnerability from those seeking broader systemic change in social and political regimes. There are three adaptation pathways: incremental, transitional and transformational, each encompassing various goals, scopes and temporal and spatial scales (Table 1).

Incremental adaptation is orientated at resilience. The main goal is to secure continuation of desired systems into the future in the face of changing contexts and uncertainty (Pelling, 2011). Climate change impacts are seen as the major source of vulnerability. The proposed solutions are centred on technological and managerial fixes that are responsive to a particular event or have a preventative character. Transitional adaptation is reformist. It involves changes to social relations and behaviour within the prevailing order (Pelling, 2011). 'Transitional' ideas have been guided by substantively different approaches. 'Sociotechnical transitions' (e.g., Geels, 2005) refer to a shift to a low-carbon development as an attempt to restructure the global fossil fuel-based economy through social innovations and technology. A 'sustainability transition' is required to adapt societies and economies to sustainable production and consumption (e.g., Raskin et al., 2002). 'Just transition' improves equity and considers impacts for different social groups (e.g., Evans \& Phelan, 2016). Transitional adaptation places vulnerabilities related to climate change alongside socioeconomic, political and environmental processes. The overall goal is adaptation in governance and institutions, including achieving institutional legitimacy, inclusion of previously excluded values and implementation of legal responsibilities.

The resilience- and transition-orientated approaches are criticized for downplaying the significance of real-world political processes and inequalities that shape relationships between society, environment and economy, and for their short-term technological and managerial optimism (Park et al., 2012). Taking a more critical perspective, transformational adaptation harnesses 
opportunities that challenge the status quo of existing economic and social structures and values, shifting the balance of power further towards justice (Pelling, 2011). Orientated at the root causes of vulnerability, it requires a regime change from the level of individual behaviour through to the structures of the global political economy.

This typology of adaptation pathways identifies social, cultural and political economic processes through which adaptation responses unfold. Moreover, it has value in placing adaptation pathways within the broader context of human development, justice and sustainability. Therefore, it is useful for understanding the reciprocal relations between environment and society in complex, contested and dynamic regions where mining takes place. Before explaining the methodology, we provide evidence of past and current industry, public policy and societal initiatives and characterize them using this conceptual framework.

\section{Emerging responses to climate change in mining regions}

Global climate change and earth system governance initiatives establish a framework for mining regions to address the threats and opportunities provided by climate change. International policy promotes strategic climate actions: mitigation and adaptation were set as two global responses by Article 4 of the UNFCCC (1992). In the fifth IPCC report, mitigation refers to interventions to reduce the sources or enhance the sinks of greenhouse gases and adaptation is defined as the process of adjustment to existing or expected climate change and its impacts (2014). The 2015 Paris Agreement for Climate Action sets mitigation goals to limit dangerous global warming to less than $2^{\circ} \mathrm{C}$ compared to preindustrial levels (UNFCCC, 2015).

There are global and regional scientific predictions - still uncertain - that the mining sector in the future will have to contend with different climatic conditions, with adverse impacts on industrial operations, regional economies, communities and ecosystems (IPCC, 2014). Climate change will likely alter access to water and increase risks to infrastructure, particularly in regions with higher water stress where many mines are located (Northey et al., 2017). With poorer-grade mineral deposits, less favourable environments and more unconventional methods of extraction (e.g., coal seam gas), the extra demand for energy and water will also increase the sector's footprint. In addition, extreme climatic conditions are predicted to intensify in regularity and severity (IPCC, 2014).

New governance arrangements and the shifting risks at mine sites have led to a range of initiatives in industry practice, public policy and social protest across geographical regions. We now describe emerging responses to climate change found in mining regions and consider them against our conceptual framework of adaptation pathways. We find that private and public initiatives correspond largely to incremental and transitional adaptation, while societal responses urge transformations.

\subsection{Industry initiatives}

Companies have been increasingly taking an active role in climate actions as initiators, catalysts and participants in industry-led and multi-stakeholder efforts (Bach, 2019). They have been supporting emissions reductions (Kolk \& Levy, 2001), not least by engaging in the UN Climate Change Conferences (Slezak, 2016). Some corporations have reconsidered their business models to include innovative solutions to offset their climate impacts (e.g., through renewable energy) and to enhance their sustainability performance (Bach, 2019; Tost et al., 2018).

Incremental adaptation has received prominence in the private sector's agenda (Averchenkova et al., 2016). The Global Oil and Gas Industry Association for Environmental and Social Issues (IPIECA), the International Council on Mining and Metals (ICMM) and the Business for Social Responsibility network (BSR) have developed guidelines in a suite of documents that assist companies in identifying climate change risks, preparing adaptive responses and developing climate-related sustainability reports (BSR, 2011; ICMM, 2011, 2013; IPIECA, 2013, 2016). Additionally, the 2030 Agenda for Sustainable Development and the Sustainable Development Goals established a pro-climate action focus (Goal 13) (UNSDSN, 2015). The interinstitutional White Paper "Mapping Mining to the Sustainable Development Goals" interprets Sustainable Development Goal 13 to include building climate change resilience and recognizing climate change in planning and investment in mines (WEF, 2016, p. 54).

The BSR (2011) recommends that mining companies seize the opportunity presented by climate change to collaborate with communities, governments, non-governmental organizations and development agencies in addressing climate change. The La Granja project was commissioned by the ICMM for Rio Tinto in Peru to find ways to enhance the capacity of copper mining host communities to adapt to climate change (ICMM, 2014). Another example is the Declaration on Resource Development Principles in Inuit Nunaat (parts of northern Canada, Russia, Greenland and Alaska in the USA). According to this document, resource development in the Inuit territory can only take place if it contributes to "global, national and regional efforts to curb greenhouse gas emissions and should always be seen through the reality of climate change" (ICC, 2011, art. 5). These initiatives engage different stakeholders in dialogue over climate change challenges and indicate transitional pathways to adaptation.

\subsection{Public initiatives}

Public responses are primarily orientated at transitional adaptation that includes experimentation with governance. For example, the assessment of environmental impacts required for the planning of new or expanding of existing mine sites can address actual and anticipated climate change risks (Agrawala et al., 2012). Regulatory agencies in a range of countries (Canada, the USA, Chile and the European Union) as well as international institutions (the International Finance Corporation and the World Bank) have formalized this need (Capstick et al., 2014).

Another example of governance innovation is designating no-go areas for mining that have implications for climate change adaptation. Restrictions on open pits have been applied in Costa Rica and in some provinces of Argentina and the Philippines (Gera, 2016). Belize, Costa Rica, France and New Zealand have placed constraints on offshore oil prospecting and extraction. Limiting fossil fuel supply is necessary to achieving the goals set by international climate policy: studies show that many of the world's reserves of oil (a third), gas (half) and coal (80\%) should remain underground from 2010 to 2050 (McGlade \& Ekins, 2015).

Governments of other countries continue granting licenses and providing subsidies to the mining and oil industries (e.g., Australia, Norway and Russia). Fossil fuel-rich countries experience the greatest exposure in the climate-constrained world, and they are advised to facilitate exploration and to accelerate 
Julia Loginova and Simon P.J. Batterbury

development of existing deposits in order to benefit from the oil sector, at least in the short term (Manley et al., 2016), while prospecting for other sources of revenues, as Saudi Arabia has begun to do.

Governments in regions that are vulnerable to the impacts of climate change have confronted the global mining industry, holding major polluters accountable for their impacts. The government in Kiribati proposed a global moratorium on coal mining expansion to save low-lying islands from rising seas (PIDF, 2015). The governments of the Philippines initiated a legal human rights case targeting fossil fuel companies that are among the major greenhouse gas emitters (Vidal, 2016).

Experiments in climate and resource governance are not limited by national boundaries, but are implicated in multiple forms of governance at various scales. They can clash with the complex realities of global markets, international institutions and geopolitics, causing a misfit of emerging initiatives with existing global policy. One example was an initiative proposed by the former President of Ecuador, Rafael Correa, to suspend oil extraction in the Ishpingo-Tambococha-Tiputini part of the Yasuni National Park (the Yasuni-ITT Initiative). This initiative failed because decision-makers could not resolve tensions between socio-political relations in Ecuador, the need for oil revenues, the inflexibility of international environmental governance and commitments to compensate Ecuador for lost oil revenues (Pellegrini et al., 2014).

\subsection{Societal initiatives}

Societal pressure for mining regions to address climate change includes an emerging wave of climate activism throughout the world. The lack of adequate political action on the issue has resulted in social and environmental movements that demand constrains on fossil fuel supply through pipeline protests, fossil fuel divestment proposals and anti-fracking campaigns (Piggot, 2018). Legal activism is a part of the movement. In 2016-2017, environmentalists initiated a lawsuit against the Norwegian government's plans for offshore oil extraction in the Arctic (SaveTheArctic, 2017). In Alaska, there have been legal claims to the energy sector for contributing to the loss of the island of Kivalina, where the Native Village of Kivalina is located, because of rising sea levels (Abate, 2013).

More radical perspectives include societal demands for systemic transformations to decreased material consumption, de-growth, alternative development and post-extractivist futures. Mining is no exception, and Bendell (2018) argues that the reformist approach to sustainable development, resilience and corporate sustainability is now redundant when faced with the cruel reality shown by the climate change data. His deep adaptation agenda calls for radical societal changes and facing up to impending doom (Bendell, 2018).

As new private and public actions emerge, incremental rather than deep transformational adaptation still guides the industry sector. Actions maintain a prevailing logic that extraction is inevitable but should be performed in a more sustainable manner to ensure the legitimacy and social acceptance of mining operations. Transitional ideas of restricting mining on climate grounds are very rare, usually where ecosystems and livelihoods are extremely vulnerable to the impacts of climate change or where resource deposits are small. Societal responses urge for transformational adaptation, demanding climate justice and control over development and the future. After defining a methodology for the review of the literature, we characterize current conceptualizations of adaptation in mining regions in selected literature.

\section{The review approach}

Our systematic review follows guidelines suggested by Petticrew and Roberts (2008). This approach enables us to evaluate existing knowledge while identifying gaps and directions for future research. The review strategy required us to explicitly identify inclusion and exclusion criteria. Articles were found in the Web of Science using the following combinations of words: ("mining" OR "resource extraction" OR "mineral" OR "oil") AND ("climat* chang ${ }^{\star ”}$ OR "global warming") AND ("adapt ${ }^{\star ”) ~ w i t h ~ n o ~ d a t e ~}$ restrictions. The search in May 2019 yielded a total of 672 results.

Since our interest lies in adaptation as a conceptual category, we targeted scholarly journals and excluded other sources, but acknowledge that relevant material is also published in books (e.g., Carlson et al., 2016; Newton et al., 2005; Sharma, 2017; Taylor, 2015) and as reports, such as in Canada (e.g., Duerden et al., 2014; Pearce et al., 2009) and Australia (e.g., Hodgkinson et al., 2010; Maru et al., 2012; Mason \& Giurco, 2013). We also concentrated our review on sources in English, excluding studies published in Spanish (e.g., Navarro, 2017; Seoane et al., 2013), French (e.g. Damian, 2014) and other languages. We excluded articles whose focus, according to the Web of Science categories, did not fit in the field of social sciences (we included interdisciplinary studies). As a result, 88 articles were selected as potentially relevant.

The title, keywords and abstract of each article were screened independently by two reviewers (JL, SPJB) and articles were included only if they addressed matters relevant to this review. For example, studies that addressed logging as a resource extraction activity were excluded. The lists of references were considered and compared to the preliminary selection. If not identified through our initial search, additional articles were included. At the end, 44 academic peer-reviewed articles in English were included in this systematic review.

We read each contribution and identified four aspects that characterize adaptation pathways (according to Table 1): goal, scope, time and scale. Based on these aspects, we classified the articles into three groups corresponding to types of adaptation pathways (incremental, transitional and transformational). If more than one was represented, only the most important pathway was identified. Disagreements of interpretation were resolved by discussion between the authors.

We used latent content analysis of the selected articles to identify key themes underlying the conceptualization of adaptation actions. This involved in-depth reading of all of the publications and interpretation of contextual information against the conceptual framework. In the following section, we synthesize the information and identify the dominant debates, shortcomings and learning opportunities.

\section{The current state of research on adaptation in mining regions}

The concept of adaptation to climate change has been increasingly applied to the mining context. With few articles published on the topic in the 2000s, the annual number of articles since the year 2010 has been between two and eight (Figure 1). Among the 44 articles included in this analysis, 16 articles focus on incremental adaptation, 15 report transitional adaptation 


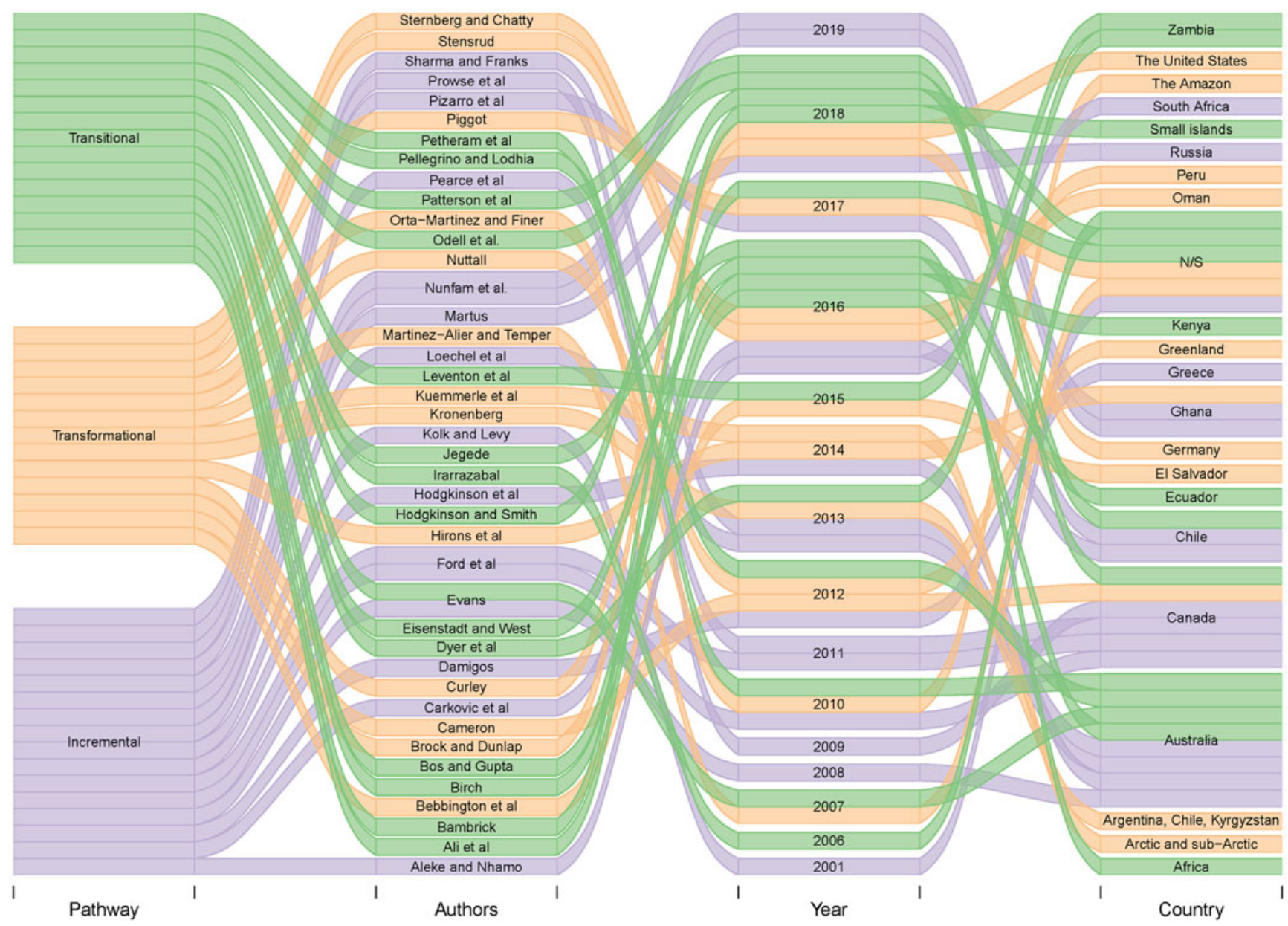

Fig. 1. Selected articles representative of Pelling's typology of adaptation pathways, year of publication and geographical coverage. Each line represents an individual article colour-coded depending on the classification into one of the three adaptation pathways. N/S = non-specified

and 13 address transformational adaptation. Some 18 countries and 4 major regions (the Arctic, the Amazon, Africa and small islands in Oceania) were covered, with a third of the studies having a defined geographical area conducted in Australia (8) and Canada (6). In approximately half of the studies, the authors reported the results of original studies that drew on qualitative and mixed-method research.

\subsection{Incremental adaptation}

The incremental adaptation pathway prevails in the assessments of vulnerability of the mining industry to climate change, its adaptive capacity and adaptation strategies in Canada and Australia. Based on surveys of mining representatives in Canada at a senior corporate (Ford et al., 2010) and mine site level (Ford et al., 2011), studies showed that a majority of informants perceived that their companies were taking engineering and administrative actions to manage the impacts of climate change. The uncertainty of climate projections and regulatory regimes and the cost of adaptation were recognized as the main barriers to action. Pearce and collaborators (2011) conducted in-depth interviews with mining professionals in Canada and found that limited adaptation planning for future climate change was underway. Diamond-mining companies in the Northwest Territories, for example, have explored alternative means of transportation and routes to adapt to warmer winter temperatures and the vulnerability of the ice road network. The adaptation strategy of sodium sulfate mines in Saskatchewan has included diverting rivers and building dikes and water storage areas in response to increased fluctuations in water supply and seasonal precipitation.

In Australia, Hodgkinson et al. (2014) synthesized findings from a range of case studies, regional workshops and surveys of over 200 mining companies. They concluded that adaptation in the mining sector in Australia was driven by "too much or too little water," with implications for access to water for processing and dust handling, interruptions to operations and flooding of pits. Adaptation strategies were related to integrated risk management, treatment and storage of groundwater, local drainage systems, advanced treatment of wastewaters and long-term forecasting for preparation for floods and storms. Another study found that adaptation activities in Australia were actually more important for local government authorities than for mining companies (Loechel et al., 2013). The authors suggested that mining companies had fewer concerns about future impacts as they discounted the risks due to a degree of climate change scepticism.

Pizarro and others (2017) documented the impacts of climate change on the Australian uranium industry (the Ranger and Olympic Dam mines) and found that tailing and waste storage facilities, ore extraction and transportation were the main operational disruptions, increasing costs and losing revenue. They 
concluded that while short-term adaptation was underway, no long-term planning to face climate risks was in place. It was suggested that the adaptive capacity of the industry could be enhanced by improving operational and management procedures, particularly communication with related companies in the supply chain.

Nunfam et al. (2019) studied mining workers' adaptation strategies to heat-exposure risks in Ghana. They demonstrated that the extent of concerns about workplace heat exposure differed significantly between small-scale and large-scale mining, and so did adaptation strategies of workers who had varying access to adequate water intake, work-break hours, shade, light clothing and cooling systems (Nunfam et al., 2019). Therefore, climate change adaptation intervention and planning should include a concerted effort among stakeholders to include observed disparities in mining activity (Nunfam et al., 2019).

In situ climate change adaptation planning in mining regions requires responsive regulations and planning frameworks. Sharma and Franks (2013) studied the experience of responses to extreme flooding in Queensland in Australia in 2007-2008 and 20102011. In this case, inflexible regulatory requirements to restrict water discharge from mine sites resulted in mines being flooded during these extreme weather events. In another case, Carkovic and collaborators (2016) urged for enhanced planning and flexible solutions in regions with abandoned mines and tailings where the risks from the exposure to climate-related events are particularly high. Knowledge-based and cost-effective strategies are needed to deal with abandoned tailings in northern Chile, a dryland region with extensive copper and iron-ore mining activities. Information and communication technology can assist in the environmental simulation and modelling that enables localized responses and adaptation. For example, just-in-time alert warning and digital electronic platforms for information sharing were employed as part of risk reduction in South Africa's mines (Aleke \& Nhamo, 2016).

Incremental adaptation strategies address the implications of climate change for the economic performance of the mining sector. Prowse and his collaborators (2009) reviewed the economic risks and opportunities for mining threatened by the impacts of climate change in Canada and argued that technological adjustments were needed to ensure economic stability and growth in the sector. Damigos (2012) quantified the economic losses from climate change for the Greek mining industry without adaptation at more than US $\$ 0.8$ billion, proposing that the cost of effective adaptation would be limited to US $\$ 312$ million.

Kolk and Levy (2001) in their study of early shifts in corporate climate strategies among oil multinationals identified factors that explain the development of climate policies: locational (e.g., regulatory policies, culture and societal concerns) and internal company-specific factors (e.g., degree of centralization and the presence of climate scientists among the staff). However, it was the market position and economic competition that affected the uptake of climate actions the most. Martus (2019) found significant variations within climate strategies employed by metals mining companies in Russia, with some firms being proactive and others reluctant. The author attributed these differences to the disproportionate effects of international and national policies on corporate strategies, as well as their varying reputational concerns.

Only one study in this group was concerned with the humanenvironment interactions in mining regions. Evans (2008) studied coal-mining communities in the Hunter Valley in Australia and argued that an essential condition for climate change adaptation in this region is action to remediate decades of open-cut coal mining, which has disrupted regional socio-ecological systems (and continues to do so).

\subsection{Transitional adaptation}

The framing of adaptation as transitional is employed in studies that suggest new approaches orientated at sustainable and climatecompatible development (CCD) in mining regions. Jegede (2016) argued that climate change adaptation could motivate sustainable mining and the green economy across African countries, for example, through the development of alternative sources of energy to use for mining and the reforestation of regions to rehabilitate abandoned mine sites. More broadly, successful co-adaptation-mitigation responses will contribute to the sustainability of mining (Hodgkinson \& Smith, 2018). Similar observations were made earlier by Irarrázabal (2006), who argued that climate change strategies are implicated in the industry's voluntary actions, particularly corporate social responsibility.

Three articles addressed the integration of the challenges and opportunities presented by climate change adaptation into the industry's voluntary actions and development efforts through CCD, defined as "development that aims to minimize the harm caused by climate impacts, while maximizing human development opportunities presented by a low emissions, more resilient future" (Dyer et al., 2013, p. 2). Leventon et al. (2015) studied the role of mining in CCD in Zambia and found that mining companies operating locally have been increasingly designing corporate social responsibility strategies to align with the need to support the livelihoods of host communities affected by climate change. This can be best achieved through partnerships, where mining companies typically provide financial resources and communities offer local expertise and labour (Dyer et al., 2013). Based on a range of case studies in Oceania (phosphate mining in Nauru and Kiribati, oil and gas mining in Timor-Leste and coal mining in West Papua and Papua New Guinea), Bambrick (2018) emphasized the importance of CCD that is health promoting and excludes resource extraction if the resilience of small-island communities is to be built.

Transitions require institutional innovations across various scales of resource and climate change governance. At the global scale, new institutional arrangements are vital to ensuring that growing demand for the minerals needed for low-carbon development does not come at the expense of environmental sustainability in places of their extraction (Ali et al., 2017). Actions are necessary along the mining value chain and must include monitoring of mineral production and consumption, coordination of mineral exploration between countries, investments in new extraction technologies, promotion of best practices and development of inventories for recyclable metals (Ali et al., 2017).

At the local scale, institutional innovations are essential to promoting greater dialogue between host communities, governments and mining companies. Eisenstadt and West (2016), in a study of perceptions and beliefs about climate change among Indigenous peoples in Ecuador, found that communities affected by oil drilling (Kichwa and Waorani peoples in Napo province) consider the 'climate change' narrative as a means to advocate against state and oil companies for their needs and rights. The authors also suggest that "indigenous people may be strong natural allies in climate change mitigation and adaptation" (Eisenstadt \& West, 2016 , p. 55), but that a dialogue has been lacking, limiting the potential of climate change adaptation to achieve sustainable 
outcomes. In Australia, Birch (2016) stressed the importance of engaging Aboriginal communities affected by mining in efforts to support climate-resilient development in an ethical and egalitarian way, based on greater recognition of traditional knowledge systems and acknowledging previous destructive impacts on their livelihoods and cultural values. The most commonly mentioned adaptation strategy for the Yolngu Aboriginal people in Arnhem Land was to establish culturally appropriate communication channels and practices that guarantee their inclusion into the management of mining and climate change impacts, recognize the Yolngu language and traditional institutions and ensure transparency and honesty in decision-making (Petheram et al., 2010).

Climate change actions by the private sector might be increasingly required for maintaining the legitimacy of mining and gaining the social license to operate (the ongoing acceptance of a company's practices). Odell et al. explain that, for the mining industry in Chile, "climate-change related pressures on water and energy resources demand that the sector goes through 'a socio-technical regime change', not only as an adaptive response, but also because in a context of climate change, 'the forms of gaining legitimacy have changed"' (Odell et al., 2018, p. 209). Pellegrino and Lodhia (2012) argued that environmental and climate disclosure by the mining industry in Australia via different media has been increasingly critical for achieving the social acceptance of mining.

The idea that our society should limit the extraction and use of fossil fuel reserves to prevent dangerous climate change (McGlade \& Ekins, 2015) has generated a debate on whether and under which conditions extraction should proceed. Bos and Gupta (2016) argued that right-to-development and equity principles should be used in planning decisions for future oil projects in the Global South. They suggest that new oil projects in Kenya should proceed because citizens of the country largely support oil extraction. This argument has also been made to support the capture of revenues from oil and gas extraction in South-East Asia's poorest nation, East Timor.

Studies also reported challenges to transitions in industrial and post-industrial countries. Evans (2007) examined the potential for a just transition in the Hunter Valley, a major coal-mining region in Australia. The author found that government sustainable interventions were lacking, and it was collective action by key labour unions, environmentalists and local residents that harnessed transitional adaptation pathways. In Canada, unprecedented fires affected oil sands-producing regions in Fort MacMurray, Alberta, in 2016. The immediate response to the disruptions was to restart oil production immediately, without questioning the implications of or for climate change. Patterson and others (2018) explained that the dominant logic of resilience-orientated adaptation and a 'jobs versus environment' discourse had prevented consideration of ending climate-damaging activities in this vulnerable region. Instead, a dialogue with oil-industry workers and civil society organizations was needed to enable alternative pathways, such as by providing support to skilled employees to transit to work in the renewable energy industry.

\subsection{Transformational adaptation}

The transformational adaptation pathway stresses the adverse fallouts from political economic structures in mining regions in which development and power are highly unequal and justice is poorly served. A representative article by Cameron (2012) critiqued the climate change adaptation research that became dominant in how adaptation is framed and addressed in northern Canada. The author argued that this literature systematically overlooks the legacy of colonialism and the profound significance of resource development in the Arctic. This omission, the author states, "contributes to a broader delimitation of Inuit political interventions into ... resource development, and climatic change" (Cameron, 2012, p. 105).

Other contributions emphasize the risks of neglecting the heterogeneity of local representation and traditional institutions, which threatens equitable climate change responses and can potentially exacerbate vulnerabilities and conflicts. Company strategies to manage carbon emissions from land-use changes, promoted by global climate change governance (e.g., REDD+, which stands for Reducing Emissions from Deforestation and Degradation), reflect an increasingly neoliberal approach to climate change actions through the commodification of carbon and payments for ecosystem services (Hirons et al., 2014). The study examined the potential of forestry to provide benefits from carbon sequestration for mining companies in Ghana, and the results suggested that these initiatives marginalized the concerns and interests of local communities and aggravated existing inequitable benefit-sharing practices through local elite capture and by alienating communities from the land (Hirons et al., 2014).

Curley (2018) studied the potential of the Green Jobs initiative of the Navajo Nation in the USA to help transition from coal dependency towards renewable energy projects. The initiative largely failed because of the complexities of the Nation's traditional governing structures and the weak legitimacy of new arrangements among community members because of its perceived neoliberal approach. Greenland is another place where traditional indigenous institutions meet the neoliberal mining agenda. However, considering relatively well-developed Greenlandic sovereignty and institutions, the outcomes are likely to be inclusive of the priorities of the Greenlandic Inuit (Nuttall, 2012). Adaptation in mining contexts where extractive culture and traditional institutions clash will never be optimal, especially when viewed against more radical options - progressive profit-sharing, cessation of mining or localized control (as, for example, in one case of majority Indigenous shareholding in nickel mining in New Caledonia).

An essential attribute of transformational adaptation is whether local communities are active in taking control over an uncertain future in the face of resource extraction activity and climate change. Peasant farmers and herders in the Peruvian Camaná-Majes-Colca watershed have engaged in creative political actions, such as claiming water rights and demanding payments from the mining companies using the water (Stensrud, 2016). The role of 'social regulation' is also evident in Kronenberg's (2013) study of open-pit mining under glaciers. The author demonstrated how the impacts of gold mining on glacier destruction elicited the social and symbolic values attached to the glaciers, helping to protect them in Argentina and Chile (with empowered societal and institutional settings), but not in Kyrgyzstan (with weak institutions and rules) (Kronenberg, 2013).

In remote regions where Indigenous and non-Indigenous people maintain subsistence lifestyles and traditional institutions are far from centres of political power and are not adapted to modern solutions, local control of mining is rare. Mining corporations, governments and development agencies have far greater power over development and land use. As a result, the extensive and poorly controlled development of mining combined with the impacts of climate change have resulted in a low chance of finding 
good-quality pastures for reindeer herds in Subarctic and Arctic climates (Kuemmerle et al., 2014) and herds in Oman (Sternberg \& Chatty, 2016), for example. The voices of the herders have been marginal in regional and national political discourses about mining. While mining has expanded, the adaptive capacity of herders has suffered.

It is challenging to implement climate change initiatives in regions where mining is dominant politically. In a discussion of governance challenges in the face of climate risks in El Salvador (a country that has recently rejected large-scale mining), Bebbington and his collaborators (2015) exposed conflicts over government mandates, particularly between economic and environmental ministries, difficulties in managing conflicts over mining leases and social development and higher-order processes governing transnationals and their actions across scales. In their view, all of these need to be resolved in El Salvador before the commencement of large-scale mining if resilience in the face of climate change risks is a concern.

Piggot (2018) argued that social movements can shift the political landscape towards restricting fossil fuel extraction. However, challenged by the 'social license to operate' in a changing climate, the mining industry can employ a range of legitimizing and repressive strategies in order to maintain mining. For example, as resistance to coal has grown in Germany, mining has been made to look 'sustainable' (Brock \& Dunlap, 2018). Moreover, mine-operating companies have employed political lobbying and overtly repressive techniques to continue operations of the Hambach open-pit coal mine, one of the world's largest (Brock \& Dunlap, 2018).

Society-wide solutions are needed not only to lower the demand for unsustainable sources of energy, but also to contribute to the mitigation of the impacts of resource extraction locally and regionally (Martinez-Alier \& Temper, 2007). Orta-Martínez and Finer, in concluding their study of Achuar peoples' resistance methods to oil extraction in the Amazon, suggest that "other alternatives should be considered when defining the development strategy such as securing human rights, stability and peace in the whole region, helping to avoid climate change, and preserving unparalleled biodiversity at world level" (2010, p. 216).

\section{Discussion: adaptation pathways in mining regions}

The way adaptation to climate change is framed informs policy and practice with potentially profound and far-reaching implications for the future (Newman \& Park, 2003; Park et al., 2012). This review emphasizes that adaptation in mining regions can take different pathways, each with a specific goal and scope of interventions and varied temporal and spatial scales. A single concept cannot do justice to the diversity of challenges in mining regions. Drawing on the evidence summarized in the previous sections, we characterize each adaptation pathway in mining regions in Table 2.

Incremental adaptation in mining regions entails maintaining mining in place and protecting industrial infrastructure and employees while mitigating environmental disasters at mine sites. The prevalent academic debates concentrate on the following themes: assessments of vulnerability, adaptive capacity and adaptation by and for the mining industry (e.g., Ford et al., 2011; Loechel et al., 2013); in situ adaptation planning and adaptive regulations (e.g., Sharma \& Franks, 2013); offering an economic and political rationale for adaptation (e.g., Damigos, 2012); and strengthening resilience of mining regions as socio- ecological systems (e.g., Evans, 2008). Adaptation initiatives are reactive, providing reputational and economic benefits for mining companies. Positive outcomes include improved existing mining technologies and managerial practices that potentially lower the risk of serious accidents. Despite such efforts, incremental adaptation can allow mining companies to continue unsustainable and socially unjust operations that best serve established values. Opportunities for learning include enabling adaptive regulations, integration of information and communication technologies, addressing the legacy of previous mining operations and a focus on preventative rather than purely reactive initiatives.

Transition-orientated adaptation in mining regions emphasizes the potential of climate responses to motivate more sustainable mining and a greener economy through voluntary corporate initiatives and innovations in governance across different scales. Inclusion of host communities and workers in decision-making about the future of resource extraction and their more equal participation in the implementation of any initiatives are vital to ensuring inclusive and informed adaptation with more equal outcomes (e.g., Birch, 2016). Finally, studies address the legitimacy of mining projects (particularly coal and oil) within the existing climate change governance regime and the fairness of transitions away from resource extraction towards sectors that support renewable energy and better products (e.g., Bos \& Gupta, 2016). Through CCD, mining companies and governments can support local livelihoods and promote the health of communities adapting to the impacts of climate change (e.g., Dyer et al., 2013; Leventon et al., 2015). The main opportunity for learning includes more inclusive decision-making. However, the mechanisms of inclusion of local values and traditional institutions in adaptation planning in mining regions are likely to vary from region to region, requiring context- and culture-specific approaches.

Transformation-orientated studies challenge solutions aimed at maintaining the function of mining, framing mining as dangerous to people and the planet, with hazardous working environments, the displacement of local people, sustaining inequalities and poverty and further contributing to climate change. In addition, the political ecology and economy of mining regions include their colonial history, large commercial profits - sometimes shared with governments - and serious land-use conflicts (e.g., Cameron, 2012). For climate change responses to achieve sustainable and fair outcomes, development priorities other than mining must be considered, and growth-orientated and consumerist models that drive the demand for minerals and fossil fuels need to be rethought (e.g., Martinez-Alier \& Temper, 2007). Current environmental crises offer opportunities, aside from mining, for changing the ways of seeing, acting and engaging with the natural world (Bendell, 2018; Waddell et al., 2015).

While we have phrased incremental, transitional and transformational adaptation pathways targeted at mining regions as separate categories for the purposes of the review, they are intersecting and overlapping. Technical incremental efforts in fact mitigate damage to mining infrastructure as well as local communities. Transitional responses encourage new institutional arrangements for more inclusive decision-making and more efficient resource use. But we argue that the world needs to move towards transformational thinking, and the other two stages are essential but insufficient to meet the challenge of a changing climate. The overall agenda for concerned scholars, politicians, practitioners and citizens is reduction in demand for minerals and resources, particularly fossil fuels, and restricting their supply when justified. Yet mining is a necessary component to capitalist 
Table 2. Adaptation pathways in mining regions.

\begin{tabular}{|c|c|c|c|}
\hline Pathway & Incremental & Transitional & Transformational \\
\hline Goal & $\begin{array}{l}\text { Maintaining mining in place by protecting } \\
\text { industrial operations and ensuring safety } \\
\text { of employees and functioning of host } \\
\text { communities and ecosystems }\end{array}$ & Transitioning to climate-compatible mining & $\begin{array}{l}\text { Changing the values and norm systems } \\
\text { that underpin mining based on the } \\
\text { dominant capitalist production and } \\
\text { existing power relations }\end{array}$ \\
\hline Scope & $\begin{array}{l}\text { Cost-effective technological and } \\
\text { managerial solutions often integrated in } \\
\text { traditional risk management and disaster } \\
\text { planning }\end{array}$ & $\begin{array}{l}\text { Changes in mining governance, regulations, } \\
\text { planning and voluntary actions }\end{array}$ & Development paradigms \\
\hline Time & $\begin{array}{l}\text { Reactive focus on an 'event' rather than } \\
\text { proactive focus on 'potential impacts' }\end{array}$ & $\begin{array}{l}\text { Project cycle and strategic development } \\
\text { goals }\end{array}$ & Current and future generations \\
\hline Scale & Mine site and/or regional mining & $\begin{array}{l}\text { Regional, national and international } \\
\text { institutions }\end{array}$ & $\begin{array}{l}\text { Cross-scale, from local communities to } \\
\text { global }\end{array}$ \\
\hline \multirow[t]{4}{*}{$\begin{array}{l}\text { Key } \\
\text { themes }\end{array}$} & $\begin{array}{l}\text { Assessments of vulnerability, adaptive } \\
\text { capacity and adaptation of the mining } \\
\text { industry (Ford et al., 2010, 2011; } \\
\text { Hodgkinson et al., 2014; Loechel et al., } \\
\text { 2013; Nunfam et al., 2019; Pearce et al., } \\
\text { 2011; Pizarro et al., 2017) }\end{array}$ & $\begin{array}{l}\text { Climate change in the sustainable mining } \\
\text { agenda, climate-compatible development } \\
\text { and corporate social responsibility } \\
\text { (Bambrick, 2018; Dyer et al., 2013; } \\
\text { Hodgkinson \& Smith, 2018; Irarrázabal, 2006; } \\
\text { Jegede, 2016; Leventon et al., 2015) }\end{array}$ & $\begin{array}{l}\text { Climate change responses are driven by } \\
\text { neoliberal and colonial ideas and neglect } \\
\text { the heterogeneity of knowledge and } \\
\text { institutions (Cameron, 2012; Curley, 2018; } \\
\text { Hirons et al., 2014; Nuttall, 2012) }\end{array}$ \\
\hline & $\begin{array}{l}\text { In situ adaptation planning and adaptive } \\
\text { regulations (Aleke \& Nhamo, 2016; } \\
\text { Carkovic et al., 2016; Sharma \& Franks, } \\
\text { 2013) }\end{array}$ & $\begin{array}{l}\text { Alternative institutional design, promoting } \\
\text { cross-scale and polycentric institutions, and } \\
\text { integration of Indigenous and local } \\
\text { knowledge systems in decision-making (Ali } \\
\text { et al., 2017; Birch, 2016; Eisenstadt \& West, } \\
\text { 2016; Petheram et al., 2010) }\end{array}$ & $\begin{array}{l}\text { Governance and political challenges } \\
\text { (Bebbington et al., 2015) }\end{array}$ \\
\hline & $\begin{array}{l}\text { Economic and political rationale for } \\
\text { adaptation (Damigos, 2012; Kolk \& Levy, } \\
\text { 2001; Martus, 2019; Prowse et al., 2009) }\end{array}$ & $\begin{array}{l}\text { Legitimacy of mining projects (particularly } \\
\text { coal and oil) within the existing climate } \\
\text { change governance regimes and just } \\
\text { transitions (Bos \& Gupta, 2016; Evans, 2007; } \\
\text { Odell et al., 2018; Patterson et al., 2018; } \\
\text { Pellegrino \& Lodhia, 2012) }\end{array}$ & $\begin{array}{l}\text { Local control of mining and social protest } \\
\text { (Brock \& Dunlap, 2018; Kronenberg, 2013; } \\
\text { Kuemmerle et al., 2014; Piggot, 2018; } \\
\text { Stensrud, 2016; Sternberg \& Chatty, 2016) }\end{array}$ \\
\hline & $\begin{array}{l}\text { Resilience of mining regions as } \\
\text { socio-ecological systems (Evans, 2008) }\end{array}$ & - & $\begin{array}{l}\text { Alternative futures and changing frames of } \\
\text { seeing and connecting (Martinez-Alier \& } \\
\text { Temper, 2007; Orta-Martínez \& Finer, 2010) }\end{array}$ \\
\hline
\end{tabular}

economic growth providing for a growing population. It is also essential to supplying the raw materials needed for new technologies to enable renewable energy transitions. Many economies depend on mining, providing employment and livelihoods. Therefore, emphasizing priorities at a single scale (national priorities for development) or of only a single actor (e.g., the mining industry) ignores and may obscure other perspectives, reinforcing unequal power relations.

Addressing multi-scale concerns requires a better understanding of the interplay between incremental, transitional and transformational adaptation pathways. Hadarits et al. (2017) studied interdependencies among and across scales and actors in the context of adaptation pathways for Canadian agriculture and found various ways in which one type of adaptation can influence (constrain or reinforce) other types. For example, extreme events that are perceived to result in crisis situations may prompt transformation. An improved understanding of these interactions in mining regions may help identify the processes occurring within these regions that facilitate movement from one to the other.

A possible solution to handling adaptation by means of multiple pathways is to embrace 'clumsy solutions'. These allow for the inclusion of many different viewpoints to address the uneasy coexistence of incompatible goals (Verweij et al., 2006). Often, the interaction between companies, governments and local communities proves to be challenging, especially in contexts with a legacy of mining-induced conflicts. Emphasizing the coexistence of multiple viewpoints can enable renegotiation of practices based on reflection on how problems and desired outcomes are framed, by whom, with whom and at what scale, and it can contribute to finding better ways for mining regions and broader society to prepare for the future in a changing climate.

\section{Conclusion}

This article assembles the expanding research on adaptation to climate change in mining regions. In providing specific examples, the review emphasizes that initiatives under an 'adaptation' framing are many and may be substantially different. For example, studies prioritize various suggestions in relation to the status quo of mining in the changing climate. In providing an outline of some aspects of incremental, transitional and transformational adaptation pathways, we found a lack of conceptual clarity. The way that dominant narratives about adaptation have emerged in scholarly work and policy, especially through private initiatives, has led to a mine- or project-centred short-term focus, while obfuscating the role of affected communities and the broader society. Therefore, apart from improving understanding of individual adaptation pathways, there is a necessity for conceptual lenses that are polycentric, dynamic and multi-scalar. 
There remain major uncertainties on how climate change will affect mining regions and what specific vulnerabilities are. Additionally, despite a relatively broad geographical coverage (representing some 18 countries in the Global North and Global South), our review has revealed a clustering of studies in Canada and Australia. This is not representative of the distribution of resource extraction sites. There are many more struggles and ongoing conflicts in mining regions throughout the world (e.g., see The Environmental Justice Atlas, 2019). There is a need for more empirical data and research that address the variety of operations implicated in mining. For example, the type (surface or underground), scale (artisanal to large scale) and stage (exploration, extraction and abandoned mines) of mining need to be better integrated in order to accommodate substantial differences. There is little on deep-sea mining or offshore fossil fuel extraction in our sample of the literature.

While assessments of vulnerability to climate change and adaptive capacity in mining regions are important, studies should explore how to enable solutions that address the injustices that prevail in the sector between corporate power and those experiencing negative impacts locally and globally. There is a need in specific empirical case studies and action research to explore where new forms of engagement are developed with the enhancement of sustainability and justice as key goals. We hope that this review contributes to acknowledging multiple framings of adaptation and will contribute to the renegotiation of practices based on a reflection of how adaptation is framed.

Acknowledgements. We are grateful to Anthony Bebbington, Rauno Sairinen and reviewers for valuable comments on an earlier manuscript. Their advice helped to define more clearly the focus of the article.

Author contributions. JL and SPJB contributed equally to the design and implementation of the review and to the writing of the article.

Financial support. JL acknowledges the Australian Government Research Training Program Scholarship.

\section{Conflict of interest. None.}

Ethical standards. The manuscript is our own original work and does not duplicate any other previously published work. The manuscript has been submitted only to the journal Global Sustainability and it is not under consideration, accepted for publication or in press elsewhere. All listed authors know of and agree to the manuscript being submitted to the journal. The manuscript contains nothing that is abusive, defamatory, fraudulent, illegal, libellous or obscene.

\section{References}

Abate, R. S. (2013). Corporate responsibility and climate justice: a proposal for a polluter-financed relocation fund for federally recognized tribes imperiled by climate change. Fordham Environmental Law Review, 25(1), 10.

Addison, T. (2018). Climate Change and the Extractives Sector. WIDER (Working Paper 84). United Nations University.

Agrawala, S., Matus Kramer, A., Prudent-Richard, G., Sainsbury, M., \& Schreitter, V. (2012). Incorporating climate change impacts and adaptation in environmental impact assessments: opportunities and challenges. Climate and Development, 4(1), 26-39.

Aleke, B. I., \& Nhamo, G. (2016). Information and communication technology and climate change adaptation: Evidence from selected mining companies in South Africa. Jàmbá: Journal of Disaster Risk Studies, 8(3), 250.

Ali, S. H., Giurco, D., Arndt, N., Nickless, E., Brown, G., Demetriades, A., ... Yakovleva, N. (2017). Mineral supply for sustainable development requires resource governance. Nature, 543(7645), 367-372.
Auty, R. (2002). Sustaining Development in Mineral Economies: The Resource Curse Thesis. Routledge.

Averchenkova, A., Crick, F., Kocornik-Mina, A., Leck, H., \& Surminski, S. (2016). Multinational and large national corporations and climate adaptation: are we asking the right questions? A review of current knowledge and a new research perspective. Wiley Interdisciplinary Reviews: Climate Change, 7(4), 517-536.

Bach, M. (2019). The oil and gas sector: from climate laggard to climate leader? Environmental Politics, 28(1), 87-103.

Bambrick, H. (2018). Resource extractivism, health and climate change in small islands. International Journal of Climate Change Strategies and Management, 10(2), 272-288.

Bebbington, A. J., \& Bury, J. (2013). Subterranean Struggles: New Dynamics of Mining, Oil, and Gas in Latin America (Vol. 8). University of Texas Press.

Bebbington, A. J., Bury, J., Cuba, N., \& Rogan, J. (2015). Mining, risk and climate resilience in the 'other' Pacific: Latin American lessons for the South Pacific. Asia Pacific Viewpoint, 56(2), 189-207.

Bendell, J. (2018). Deep Adaptation: A Map for Navigating Climate Tragedy. Retrieved from http://insight.cumbria.ac.uk/id/eprint/4166/.

Birch, T. (2016). Climate change, mining and traditional Indigenous knowledge in Australia. Social Inclusion, 4(1), 92-101.

Bos, K., \& Gupta, J. (2016). Inclusive development, oil extraction and climate change: a multilevel analysis of Kenya. International Journal of Sustainable Development \& World Ecology, 23(6), 482-492.

Bridge, G. (2016). Resource extraction. International Encyclopedia of Geography: People, the Earth, Environment, and Technology, 1-13. Retrieved from https:// onlinelibrary.wiley.com/doi/book/10.1002/9781118786352.

Brock, A., \& Dunlap, A. (2018). Normalising corporate counterinsurgency: engineering consent, managing resistance and greening destruction around the Hambach coal mine and beyond. Political Geography, 62, 33-47.

BSR (2011). Adapting to Climate Change: A Guide for the Mining Industry. Retrieved from https://www.bsr.org/collaboration/groups/resilience-andadaptation-initiative.

Cameron, E. S. (2012). Securing Indigenous politics: a critique of the vulnerability and adaptation approach to the human dimensions of climate change in the Canadian Arctic. Global Environmental Change, 22(1), 103-114.

Capstick, S., Kelly, J., Barrett, A., \& Penailillo, R. (2014). Incorporating climate change impacts into environmental assessments. Paper presented at the 34th Annual Conference of the International Association for Impact Assessment. Retrieved from http://conferences.iaia.org/2014/IAIA14-finalpapers/Capstick,\%20Sean.\%20\%20Incorporating\%20climate\%20change\% 20impacts\%20into\%20EA.pdf.

Carkovic, A. B., Calcagni, M. S., Vega, A. S., Coquery, M., Moya, P. M., Bonilla, C. A., \& Pastén, P. A. (2016). Active and legacy mining in an arid urban environment: challenges and perspectives for Copiapó, Northern Chile. Environmental Geochemistry and Health, 38(4), 1001-1014.

Carlson, C., Goldman, G., \& Dahl, K. (2016). Stormy seas, rising risks: assessing undisclosed risk from sea level rise and storm surge at coastal US oil refineries. In L. J. Drake, Y. Y. Kontar, C. J. Eichelberger, S. T. Rupp, \& M. K. Taylor (eds), Communicating Climate-Change and Natural Hazard Risk and Cultivating Resilience: Case Studies for a Multi-disciplinary Approach (pp. 295-308). Springer International Publishing.

Curley, A. (2018). A failed green future: Navajo Green Jobs and energy 'transition' in the Navajo Nation. Geoforum, 88, 57-65.

Damian, M. (2014). Mauvaise nouvelle pour le climat et les peuples de l'Amazonie équatorienne: l'abandon du projet Yasuni-ITT de gel du pétrole en terre. Natures Sciences Sociétés, 21(4), 428-435.

Damigos, D. (2012). Monetizing the impacts of climate change on the Greek mining sector. Mitigation and Adaptation Strategies for Global Change, 17 (8), 865-878.

Duerden, F., Pearce, T., Ford, J., \& Pittman, J. (2014). Case Studies of Climate Change in the Yukon Mining Sector: From Planning and Operation to Remediation and Restoration. Climate Change Impacts and Adaptation Division.

Dyer, J., Leventon, J., Stringer, L., Dougill, A., Syampungani, S., Nshimbi, M., ... Kafwifwi, A. (2013). Partnership models for climate compatible development: experiences from Zambia. Resources, 2(1), 1-25. 
Eisenstadt, T. A., \& West, K. J. (2016). Indigenous belief systems, science, and resource extraction: climate change attitudes in Ecuador. Global Environmental Politics, 17(1), 40-58.

The Environmental Justice Atlas (2019). World map. Retrieved from https:// ejatlas.org.

Evans, G. (2007). A just transition from coal to renewable energy in the Hunter Valley of New South Wales, Australia. International Journal of Environment, Workplace and Employment, 3(3-4), 175-194.

Evans, G. (2008). Transformation from 'carbon valley' to a 'post-carbon society' in a climate change hot spot: the coalfields of the Hunter Valley, New South Wales, Australia. Ecology and Society, 13(1). Retrieved from http:// www.ecologyandsociety.org/vol13/iss1/art39/.

Evans, G., \& Phelan, L. (2016). Transition to a post-carbon society: linking environmental justice and just transition discourses. Energy Policy, 99, 329-339.

Ford, J. D., Pearce, T., Prno, J., Duerden, F., Berrang Ford, L., Beaumier, M., \& Smith, T. (2010). Perceptions of climate change risks in primary resource use industries: a survey of the Canadian mining sector. Regional Environmental Change, 10(1), 65-81.

Ford, J. D., Pearce, T., Prno, J., Duerden, F., Ford, L. B., Smith, T. R., \& Beaumier, M. (2011). Canary in a coal mine: perceptions of climate change risks and response options among Canadian mine operations. Climatic Change, 109(3-4), 399-415.

Füssel, H. M. (2007). Adaptation planning for climate change: concepts, assessment approaches, and key lessons. Sustainability Science, 2(2), 265-275.

Geels, F. W. (2005). Technological Transitions and System Innovations: A Co-evolutionary and Socio-technical Analysis. Edward Elgar.

Gera, W. (2016). Examining the resilience of public participation structures for sustainable mining in the Philippines. In V. Mauerhofer (ed.), Legal Aspects of Sustainable Development: Horizontal and Sectoral Policy Issues (pp. 203231). Springer International Publishing.

Gillard, R., Gouldson, A., Paavola, J., \& Van Alstine, J. (2016). Transformational responses to climate change: beyond a systems perspective of social change in mitigation and adaptation. Wiley Interdisciplinary Reviews: Climate Change, 7(2), 251-265.

Giurco, D., \& Cooper, C. (2012). Mining and sustainability: asking the right questions. Minerals Engineering, 29, 3-12.

Hadarits, M., Pittman, J., Corkal, D., Hill, H., Bruce, K., \& Howard, A. (2017). The interplay between incremental, transitional, and transformational adaptation: a case study of Canadian agriculture. Regional Environmental Change, 17(5), 1515-1525.

Hilson, G. (2002). An overview of land use conflicts in mining communities. Land Use Policy, 19(1), 65-73.

Hirons, M., Hilson, G., Asase, A., \& Hodson, M. E. (2014). Mining in a changing climate: what scope for forestry-based legacies? Journal of Cleaner Production, 84, 430-438.

Hodgkinson, J., Hobday, A. J., \& Pinkard, E. A. (2014). Climate adaptation in Australia's resource-extraction industries: ready or not? Regional Environmental Change, 14(4), 1663-1678.

Hodgkinson, J., Littleboy, A., Howden, M., Moffat, K., \& Loechel, B. (2010). Climate Adaptation in the Australian Mining and Exploration Industries. Climate Adaptation Flagship Working Paper.

Hodgkinson, J. H., \& Smith, M. H. (2018). Climate change and sustainability as drivers for the next mining and metals boom: the need for climate-smart mining and recycling. Resources Policy. doi:10.1016/j.resourpol.2018.05.016.

Hoffmann, A. A., \& Sgro, C. M. (2011). Climate change and evolutionary adaptation. Nature, 470(7335), 479-485.

ICC (2011). A Circumpolar Inuit Declaration on Resource Development Principles in Inuit Nunaat. Retrieved from http://inuit.org/about-icc/iccdeclarations/declaration-on-resource-development-principles-2011.

ICMM (2011). ICMM Principles for Climate Change Policy Design Position Statement. Retrieved from https://www.icmm.com/en-gb/members/membercommitments/position-statements/icmm-principles-for-climate-changepolicy-design-position-statement.

ICMM (2013). Adapting to a Changing Climate: Implications for the Mining and Metals Industry. Retrieved from https://www.icmm.com/en-gb/publications/climate-change/adapting-to-a-changing-climate-implications-for-themining-and-metals-industry.
ICMM (2014). La Granja Project. Retrieved from https://www.icmm.com/ website/case-studies/2016_la-granja-case-study.pdf.

IPCC (2014). Climate change 2014: impacts, adaptation, and vulnerability. Part A: global and sectoral aspects. In C. B. Field, V. R. Barros, D. J. Dokken, K. J. Mach, M. D. Mastrandrea, T. E. Bilir, ... L. L. White (eds), Contribution of Working Group II to the Fifth Assessment Report of the Intergovernmental Panel on Climate Change (p. 1132). Cambridge University Press.

IPIECA (2013). Addressing Adaptation in the Oil and Gas Industry. Retrieved from http://www.ipieca.org/news/addressing-adaptation-in-the-oil-and-gasindustry/.

IPIECA (2016). IPIECA Climate Change Reporting Framework: A Pilot Guidance Document for the Oil and Gas Industry. Retrieved from http:// www.ipieca.org/resources/good-practice/ipieca-climate-change-reportingframework.

Irarrázabal, R. (2006). Mining and climate change: towards a strategy for the industry. Journal of Energy \& Natural Resources Law, 24(3), 403-422.

Jegede, A. O. (2016). The environmental and economic implications of the climate change and extractive industry nexus in Africa. Environmental Economics, 7(4), 95-103.

Kemp, D., Owen, J. R., Gotzmann, N., \& Bond, C. J. (2011). Just relations and company-community conflict in mining. Journal of Business Ethics, 101(1), 93-109.

Kolk, A., \& Levy, D. (2001). Winds of change: corporate strategy, climate change and oil multinationals. European Management Journal, 19(5), 501-509.

Kronenberg, J. (2013). Linking ecological economics and political ecology to study mining, glaciers and global warming. Environmental Policy \& Governance, 23(2), 75-90.

Kuemmerle, T., Baskin, L., Leitão, P., Prishchepov, A., Thonicke, K., \& Radeloff, V. (2014). Potential impacts of oil and gas development and climate change on migratory reindeer calving grounds across the Russian Arctic. Diversity and Distributions, 20(4), 416-429.

Leach, M., Reyers, B., Bai, X., Brondizio, E. S., Cook, C., Díaz, S., ... Subramanian, S. M. (2018). Equity and sustainability in the Anthropocene: a social-ecological systems perspective on their intertwined futures. Global Sustainability, 1, e13.

Leventon, J., Dyer, J. C., \& Van Alstine, J. D. (2015). The private sector in climate governance: opportunities for climate compatible development through multilevel industry-government engagement. Journal of Cleaner Production, 102, 316-323.

Loechel, B., Hodgkinson, J., \& Moffat, K. (2013). Climate change adaptation in Australian mining communities: comparing mining company and local government views and activities. Climatic Change, 119(2), 465-477.

Magnan, A. K., Schipper, E. L. F., Burkett, M., Bharwani, S., Burton, I., Eriksen, S., ... Ziervogel, G. (2016). Addressing the risk of maladaptation to climate change. Wiley Interdisciplinary Reviews: Climate Change, 7(5), 646-665.

Manley, D., Cust, J., \& Cecchinato, G. (2016). Stranded Nations? The Climate Policy Implications for Fuel-Rich Developing Countries. Policy Paper 34. OxCarre.

Martinez-Alier, J., \& Temper, L. (2007). Oil and climate change: voices from the south. Economic and Political Weekly, 42(50), 16-19.

Martus, E. (2019). Russian industry responses to climate change: the case of the metals and mining sector. Climate Policy, 19, 17-29.

Maru, Y. T., Chewings, V., \& Sparrow, A. (2012). Climate Change Adaptation, Energy Futures and Carbon Economies in Remote Australia: A Review of the Current Literature, Research and Policy. Working Paper CW005. Ninti One Ltd.

Mason, L., \& Giurco, D. (2013). Climate Change Adaptation for Australian Minerals Industry Professionals. National Climate Change Adaptation Research Facility.

McGlade, C., \& Ekins, P. (2015). The geographical distribution of fossil fuels unused when limiting global warming to $2^{\circ} \mathrm{C}$. Nature, 517(7533), 187-190.

Naess, L. O., Newell, P., Newsham, A., Phillips, J., Quan, J., \& Tanner, T. (2015). Climate policy meets national development contexts: insights from Kenya and Mozambique. Global Environmental Change, 35, 534-544.

Navarro, H. F. (2017). Glaciares del semiárido chileno en el contexto de cambio climático y explotación minera. Espacios, 7(13), 17-26. 
Newman, M. E., \& Park, J. (2003). Why social networks are different from other types of networks. Physical Review E, 68(3), 036122.

Newton, J., Paci, C. J., \& Ogden, A. (2005). Climate change and natural hazards in northern Canada: integrating indigenous perspectives with government policy. In C. E. Haque (ed.), Mitigation of Natural Hazards and Disasters: International Perspectives (pp. 209-239): Springer.

Northey, S. A., Mudd, G. M., Werner, T. T., Jowitt, S. M., Haque, N., Yellishetty, M., \& Weng, Z. (2017). The exposure of global base metal resources to water criticality, scarcity and climate change. Global Environmental Change, 44, 109-124.

Nunfam, V. F., Oosthuizen, J., Adusei-Asante, K., Van Etten, E. J., \& Frimpong, K. (2019). Perceptions of climate change and occupational heat stress risks and adaptation strategies of mining workers in Ghana. Science of the Total Environment, 657, 365-378.

Nunfam, V. F., Van Etten, E. J., Oosthuizen, J., Adusei-Asante, K., \& Frimpong, K. (2019). Climate change and occupational heat stress risks and adaptation strategies of mining workers: perspectives of supervisors and other stakeholders in Ghana. Environmental Research, 169, 147-155.

Nuttall, M. (2012). Imagining and governing the Greenlandic resource frontier. The Polar Journal, 2(1), 113-124.

O'Brien, K. (2012). Global environmental change II: from adaptation to deliberate transformation. Progress in Human Geography, 36(5), 667-676.

O'Rourke, D., \& Connolly, S. (2003). Just oil? The distribution of environmental and social impacts of oil production and consumption. Annual Review of Environment and Resources, 28(1), 587-617.

Odell, S. D., Bebbington, A., \& Frey, K. E. (2018). Mining and climate change: a review and framework for analysis. The Extractive Industries and Society, 5 (1), 201-214.

Orta-Martínez, M., \& Finer, M. (2010). Oil frontiers and Indigenous resistance in the Peruvian Amazon. Ecological Economics, 70(2), 207-218.

Park, S., Marshall, N. A., Jakku, E., Dowd, A.-M., Howden, S. M., Mendham, E., \& Fleming, A. (2012). Informing adaptation responses to climate change through theories of transformation. Global Environmental Change, 22(1), 115-126.

Patterson, J. J., Thaler, T., Hoffmann, M., Hughes, S., Oels, A., Chu, E., ... Jordan, A. (2018). Political feasibility of $1.5^{\circ} \mathrm{C}$ societal transformations: the role of social justice. Current Opinion in Environmental Sustainability, 31, 1-9.

Pearce, T., Ford, J. D., Prno, J., \& Duerden, F. (2009). Climate Change and Canadian Mining: Opportunities for Adaptation. David Suzuki Foundation.

Pearce, T., Ford, J. D., Prno, J., Duerden, F., Pittman, J., Beaumier, M., ... Smit, B. (2011). Climate change and mining in Canada. Mitigation and Adaptation Strategies for Global Change, 16(3), 347-368.

Pellegrini, L., Arsel, M., Falconí, F., \& Muradian, R. (2014). The demise of a new conservation and development policy? Exploring the tensions of the Yasuní ITT initiative. The Extractive Industries and Society, 1(2), 284-291.

Pellegrino, C., \& Lodhia, S. (2012). Climate change accounting and the Australian mining industry: exploring the links between corporate disclosure and the generation of legitimacy. Journal of Cleaner Production, 36, 68-82.

Pelling, M. (2011). Adaptation to Climate Change: From Resilience to Transformation. Routledge.

Petheram, L., Zander, K., Campbell, B., High, C., \& Stacey, N. (2010). 'Strange changes': Indigenous perspectives of climate change and adaptation in $\mathrm{NE}$ Arnhem Land (Australia). Global Environmental Change, 20(4), 681-692.

Petticrew, M., \& Roberts, H. (2008). Systematic Reviews in the Social Sciences: A Practical Guide: John Wiley \& Sons.

Phillips, J. (2016). Climate change and surface mining: a review of environment-human interactions and their spatial dynamics. Applied Geography, $74,95-108$.

PIDF (2015). SUVA Declaration on Climate Change. Retrieved from http:// pacificidf.org/suva-declaration-on-climate-change/.

Piggot, G. (2018). The influence of social movements on policies that constrain fossil fuel supply. Climate Policy, 18(7), 942-954.
Pizarro, J., Sainsbury, B., Hodgkinson, J., \& Loechel, B. (2017). Australian uranium industry climate change vulnerability assessment. Environmental Development, 24, 109-123.

Prowse, T. D., Furgal, C., Chouinard, R., Melling, H., Milburn, D., \& Smith, S. L. (2009). Implications of climate change for economic development in northern Canada: energy, resource, and transportation sectors. AMBIO: A Journal of the Human Environment, 38(5), 272-281.

Raskin, P., Banuri, T., Gallopin, G., Gutman, P., Hammond, A., Kates, R., \& Swart, R. (2002). Great Transition: The Promise and Lure of the Times Ahead. Stockholm Environment Institute.

SaveTheArctic (2017). The Climate Lawsuit against the Norwegian Government. Retrieved from https://www.savethearctic.org/en/peoplevsarcticoil/background-documents/.

Segura-Salazar, J., \& Tavares, L. (2018). Sustainability in the minerals industry: seeking a consensus on its meaning. Sustainability, 10(5), 1429.

Seoane, J., Taddei, E., Algranati, C., \& Borón, A. (2013). Extractivismo, despojo y crisis climática: Desafíos para los movimientos sociales y los proyectos emancipatorios de nuestra América. Ediciones Herramienta.

Sharma, V. (2017). Mining and climate change. In T. O'Callaghan \& G. Graetz (eds), Mining in the Asia-Pacific (pp. 301-320). Springer.

Sharma, V., \& Franks, D. M. (2013). In situ adaptation to climatic change: mineral industry responses to extreme flooding events in Queensland Australia. Society \& Natural Resources, 26(11), 1252-1267.

Slezak, M. (2016). Marrakech climate talks: giving the fossil fuel lobby a seat at the table. The Guardian. Retrieved from https://www.theguardian.com/ environment/2016/nov/07/marrakech-climate-talks-giving-the-fossil-fuellobby-a-seat-at-the-table.

Smit, B., \& Wandel, J. (2006). Adaptation, adaptive capacity and vulnerability. Global Environmental Change, 16(3), 282-292.

Stensrud, A. B. (2016). Harvesting water for the future: reciprocity and environmental justice in the politics of climate change in Peru. Latin American Perspectives, 43(4), 56-72.

Sternberg, T., \& Chatty, D. (2016). Marginality, climate and resources in pastoral rangelands: Oman and Mongolia. Rangelands, 38(3), 145-151.

Taylor, M. (2015). The Political Ecology of Climate Change Adaptation: Livelihoods, Agrarian Change and the Conflicts of Development. Routledge.

Thornton, T. F., \& Comberti, C. (2017). Synergies and trade-offs between adaptation, mitigation and development. Climatic Change, 140(1), 5-18.

Tost, M., Hitch, M., Chandurkar, V., Moser, P., \& Feiel, S. (2018). The state of environmental sustainability considerations in mining. Journal of Cleaner Production, 182, 969-977.

UNFCCC (1992). United Nations Framework Convention on Climate Change. Retrieved from https://unfccc.int/files/essential_background/background_publications_htmlpdf/application/pdf/conveng.pdf.

UNFCCC (2015). The Paris Agreement. Retrieved from http://unfccc.int/ resource/docs/2015/cop21/eng/109r01.pdf.

UNSDSN (2015). Transforming Our World: The 2030 Agenda for Sustainable Development. Retrieved from http://unsdsn.org/resources/publications/anaction-agenda-for-sustainable-development/.

Verweij, M., Douglas, M., Ellis, R., Engel, C., Hendriks, F., Lohmann, S., ... Thompson, M. (2006). Clumsy solutions for a complex world: the case of climate change. Public Administration, 84(4), 817-843.

Vidal, J. (2016). World's largest carbon producers face landmark human rights case. The Guardian. Retrieved from https:/www.theguardian.com/environment/2016/jul/27/worlds-largest-carbon-producers-face-landmark-humanrights-case.

Waddell, S., Waddock, S., Cornell, S., Dentoni, D., McLachlan, M., \& Meszoely, G. (2015). Large systems change: an emerging field of transformation and transitions. Journal of Corporate Citizenship, 58, 5-30.

WEF (2016). Mapping Mining to the Sustainable Development Goals: An Atlas. Retrieved from http://unsdsn.org/resources/publications/mappingmining-to-the-sustainable-development-goals-an-atlas/. 